\title{
Cellular Translational Reporter Assay
}

Taishi Kimura and Kiyoshi Takeda*

Department of Microbiology and Immunology, Graduate School of Medicine, Osaka University, Suita, Japan

*For correspondence: ktakeda@ongene.med.osaka-u.ac.jp

[Abstract] The method described here allows measuring the effect of exogenously introduced modifications to in vitro-transcribed mRNA on the translation in cells. Using cells derived from knockout mice and control littermates, this method enables to compare the results in the presence or absence of specific gene products. In our lab, we used this protocol to check whether the exogenous addition of 5' capping and 2'-O methylation to in vitro-mRNA affects the translational efficiency. Here we describe the details of our experiments.

\section{Materials and Reagents}

1. Mouse embryonic fibroblasts (prepared from day 14.5 embryos)

2. Vector pGL4.14 (Luc2 encoding vector) (Promega Corporation, catalog number: E6691)

3. Primers (Invitrogen custom DNA primers)

a. 5'-TAATACGACTCACTATAGGCCACCATGGAAGATGCCAAAAA-3' (the T7 class III promoter sequence is underlined)

b. 5'-TACCACATTTGTAGAGGTTTTACTTGCTTT-3'

4. rTaq DNA polymerase (TOYOBO, catalog number: TAP-211)

5. Agarose gel

6. Ethidium bromide

7. Illustra GFX PCR and Gel Band Purification Kit (GE Healthcare, catalog number: 28-9034-71)

8. MEGAScript In vitro transcription Kit (Life Technologies, Ambion ${ }^{\circledR}$, catalog number: AM1333)

Note: Nuclease-free Water and LiCl Precipitation Solution are included in the kit.

9. $80 \%$ ethanol

10. ScriptCap m7G capping system (EpiCentre, catalog number: SCCE0610)

11. ScriptCap 2'-O-Methyltransferase Kit (EpiCentre, catalog number: SCMT0610)

12. RNeasy Mini Kit (QIAGEN, catalog number: 74104)

13. Opti-MEM I Reduced Serum Medium (Life Technologies, Gibco ${ }^{\circledR}$, catalog number: 31985-070) 
14. D-PBS(-) (Nacalai Tesque, catalog number: 14249-95)

15. Lipofectamine 2000 DNA Transfection Reagent (Life Technologies, catalog number: 11668-019)

16. Dual-luciferase reporter assay system (Promega Corporation, catalog number: E1960)

17. BCA Protein Assay Reagent (Thermo Fisher Scientific, catalog number: 23227)

\section{Equipment}

1. Cell scraper

2. GeneAmp PCR system 9700 (Applied Biosystems ${ }^{\circledR}$ )

3. Centrifugal Concentrator CC105 (TOMY)

4. Lumat LB 9507 Luminometer (Bertjold Technologies)

5. Model 680 Microplate Reader (Bio-Rad Laboratories)

\section{Procedure}

A. Subcloning of Luc2 cDNA

1. Prepare the polymerase chain reaction mix.

Mix following components on ice:

$0.2 \mu \mathrm{l}$ of rTaq DNA polymerase

$5 \mu$ of $10 x$ Buffer $(+M g)$ for rTaq

$5 \mu$ of dNTPs ( $2 \mathrm{mM}$ each)

$4 \mu \mathrm{l}$ of primers (10 mM each of Forward and Reverse primers)

$1 \mu \mathrm{l}$ of vector pGL4.14 (100 ng)

$35 \mu$ of water

2. Run the polymerase chain reaction.

Place the reaction mix to the GeneAmp PCR system 9700 .

PCR program:

Step 1: $94{ }^{\circ} \mathrm{C} 5 \mathrm{~min}$

Step 2: $94{ }^{\circ} \mathrm{C} 30 \mathrm{sec}$

Step 3: $60^{\circ} \mathrm{C} 2 \mathrm{~min}$

Step 4: $74{ }^{\circ} \mathrm{C} 1 \mathrm{~min}$ (repeat steps $2-4$ for 35 times)

Step 5: $74{ }^{\circ} \mathrm{C} 10 \mathrm{~min}$

3. Purification of PCR amplified fragments.

a. Electrophorese the PCR products on $1 \%$ of agarose gel.

b. Stain Gel with Ethidium Bromide.

C. Cut the gel region including an amplified DNA fragment (approximately 1.6-kbp). 
d. Purify PCR amplified DNA from gels using illustra GFX PCR and Gel Band Purification Kit.

Note: In this process, we elute DNA fragment with $30 \mu \mathrm{l}$ of Nuclease-free Water (8 $\mu \mathrm{l}$ aliquots of the eluent are used as a template DNA for following in vitro transcription).

B. In vitro transcription of Luciferase mRNA under the control of T7 promoter

1. Prepare the in vitro transcription mix.

Mix following components at room temperature:

$8 \mu$ of Template DNA

$2 \mu \mathrm{l}$ of $10 x$ Reaction Buffer

$2 \mu$ of $10 \mathrm{mM}$ ATP

$2 \mu \mathrm{l}$ of $10 \mathrm{mM}$ CTP

$2 \mu \mathrm{l}$ of $10 \mathrm{mM}$ UTP

$2 \mu \mathrm{l}$ of $10 \mathrm{mM}$ GTP

$2 \mu \mathrm{l}$ of T7 Enzyme Mix

Mix thoroughly with pipetting.

2. Incubate at $37^{\circ} \mathrm{C}, 4 \mathrm{~h}$.

3. Add $2 \mu \mathrm{l}$ of TURBO DNase (a component of MEGAScript) to digest the rest template DNA and incubate $15 \mathrm{~min}$ at $37^{\circ} \mathrm{C}$ on the block incubator.

4. RNA extraction with lithium chloride $(\mathrm{LiCl})$ precipitation.

a. Add $30 \mu \mathrm{l}$ of Nuclease-free Water and $30 \mu \mathrm{l}$ of $\mathrm{LiCl}$ Precipitation Solution to the in vitro transcription products.

b. Mix thoroughly with vortex mixer. Chill for $1 \mathrm{~h}$ at $-20^{\circ} \mathrm{C}$.

c. Centrifuge at $4{ }^{\circ} \mathrm{C}$ for $15 \mathrm{~min}$ at $15,000 \mathrm{rpm}$.

d. Discard the supernatants, and wash the pellet with $1 \mathrm{ml}$ of $80 \%$ ethanol.

e. Centrifuge at $4{ }^{\circ} \mathrm{C}$ for $15 \mathrm{~min}$ at $15,000 \mathrm{rpm}$.

f. Discard the supernatants, and dry the pellet with centrifugal concentrator CC105 for 5 $\min$.

g. Resuspend the RNA in $20 \mu \mathrm{l}$ of Nuclease-free Water, and stored at $-80{ }^{\circ} \mathrm{C}$.

C. Enzymatic modification of RNA 5' end

1. Add $m 7 G$ cap, or $m 7 G$ cap and 2'-O methylation to the in vitro-transcribed RNA with ScriptCap system.

a. Adjust the volume of transcribed RNA $(50 \mu \mathrm{g})$ to $67 \mu \mathrm{l}$ with Nuclease-free Water.

b. Denature the RNA at $65^{\circ} \mathrm{C}$ for $10 \mathrm{~min}$, then transfer the tube immediately to ice.

c. While the RNA is denaturing, mix following components:

$10 \mu \mathrm{l}$ of $10 \mathrm{x}$ ScriptCap Capping Buffer

Copyright @ 2014 The Authors; exclusive licensee Bio-protocol LLC. 
$10 \mu \mathrm{l}$ of $10 \mathrm{mM}$ GTP

$2.5 \mu \mathrm{l}$ of $20 \mathrm{mM}$ SAM

$2.5 \mu \mathrm{l}$ of ScriptGuard RNase Inhibitor

$4 \mu \mathrm{l}$ of ScriptCap 2'-O-Methyltrasferase (100 U/ $\mu \mathrm{l})$ for 2'-O methylated 5' capped RNA or Nuclease-free Water for 2'-O unmethylated 5' capped RNA

d. Add $4 \mu \mathrm{l}$ of ScriptCap Capping Enzyme $(10 \mathrm{U} / \mu \mathrm{l})$ and $67 \mu \mathrm{l}$ of denatured RNA to the reaction cocktail from step $\mathrm{C} 1 \mathrm{c}$.

e. Incubate at $37^{\circ} \mathrm{C}$ for $2 \mathrm{~h}$.

f. Reaction products were purified with an RNeasy Mini Kit.

D. RNA transfection with mouse embryonic fibroblasts.

1. Seed a $35 \mathrm{~mm}$ diameter dish with $2 \times 10^{5}$ mouse embryonic fibroblasts in $1 \mathrm{ml}$ DMEM, and incubate $24 \mathrm{~h}$.

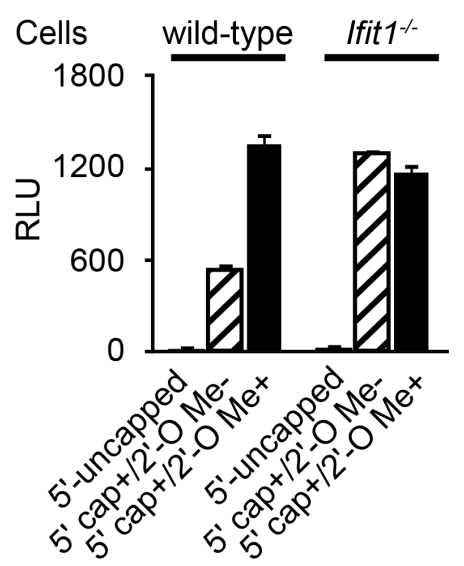

Figure 1. Luciferase activity of introduced RNAs. Wild-type and Ifit1-deficient (Ifit1-/-) mouse embryonic fibroblasts were transiently transfected with three different types of luciferase mRNAs (5'-uncapped, 5' capped but 2'-O unmethylated; 5' cap+/2'-O Me-, 5' capped and 2'-O methylated; 5' cap+/2'-O Me+). Luciferase activities are shown as relative light units $(R L U)$, and the numbers of RLU were normalized by the concentrations of proteins determined in step E1d. Data are shown as means \pm SDs of triplicate samples. These data show that Ifit1 selectively inhibits the translation of 5' capped but 2'-O unmethylated (5' cap+/2'-O Me-) luciferase mRNA.

2. Transfect RNA using Lipofectamine 2000.

a. Dilute $10 \mu \mathrm{l}$ of Lipofectamine 2000 DNA Transfection Reagent in $240 \mu \mathrm{l}$ of Opti-MEM medium per sample.

b. Dilute $2 \mu \mathrm{g}$ of luciferase RNA in $250 \mu$ l of Opti-MEM medium. 
c. Add $250 \mu$ of diluted Lipofectamine 2000 DNA Transfection Reagent to $250 \mu \mathrm{l}$ of diluted Luciferase RNA. Mix thoroughly.

d. Incubate at room temperature for $15 \mathrm{~min}$.

e. Add RNA-lipid complex to the mouse embryonic fibroblasts, and incubate for $6 \mathrm{~h}$.

E. Luciferase translational reporter assays

1. Preparation of cell lysates.

a. After incubation for $6 \mathrm{~h}$, wash the RNA-transfected mouse embryonic fibroblasts with D-PBS(-) twice.

b. Add $100 \mu \mathrm{l}$ of $1 \mathrm{x}$ passive lysis buffer and harvest cells with cell scraper.

c. Centrifuge at $4{ }^{\circ} \mathrm{C}$ for $15 \mathrm{~min}$ at $15,000 \mathrm{rpm}$.

d. Determine the protein concentration in $5 \mu$ aliquots of the supernatants by BCA Protein Assay.

e. Add equal protein amount (determined by BCA protein assay) of aliquots of the supernatants to $50 \mu$ of Luciferase Assay Reagent II (LAR II).

f. Immediately, measure the relative luciferase units (RLUs) on Lumat LB 9507 Luminometer according to the manufacturer's instruction.

\section{Acknowledgments}

This work was adapted from the following paper: Kimura et al. (2013). This work was supported by grants from the Ministry of Education, Culture, Sports, Science and Technology, the Japan Science and Technology Agency, and by the Ministry of Health, Labour and Welfare.

\section{References}

1. Kimura, T., Katoh, H., Kayama, H., Saiga, H., Okuyama, M., Okamoto, T., Umemoto, E., Matsuura, Y., Yamamoto, M. and Takeda, K. (2013). Ifit1 inhibits Japanese encephalitis virus replication through binding to $5^{\prime}$ capped 2'-O unmethylated RNA. J Virol 87(18): 9997-10003. 